\title{
Can you teach an old dog new tricks? An exploratory study into how a sample of lecturers develop digital literacies as part of their career development
}

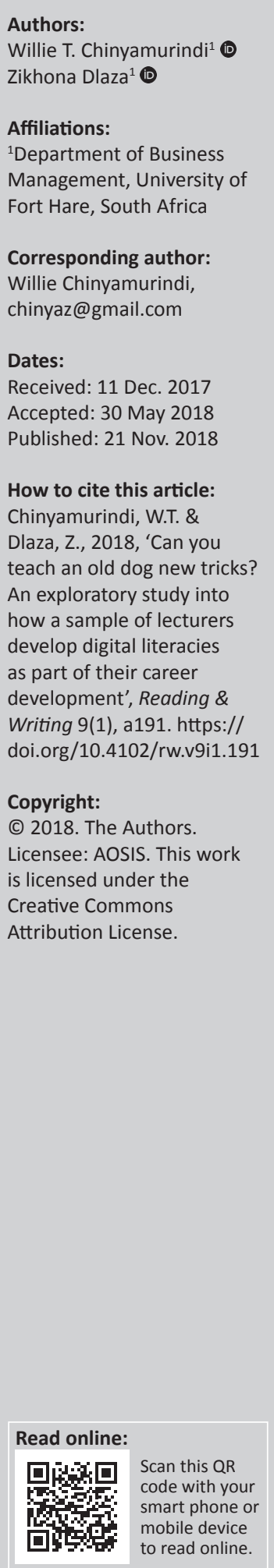

The concept of digital and information communication technology (ICT) literacy is receiving renewed empirical attention. This focus is attributed to the changing nature of society and the move towards the ideals of the knowledge-based economy. Further, universities in South Africa and internationally are encouraging the fusion of technology in how students read and write. This research gives focus to the lecturer, particularly those lecturers who were once resistant to the use of technology as part of teaching instruction. The aim here was to track how these lecturers over a one-year period develop digital and ICT literacies to assist their career development. The study adopted an interpretivist philosophy, relying on the qualitative research approach and a series of three interviews over a year period with 20 lecturers at a selected South African university. Data were analysed using thematic analysis to generate three central themes. Firstly, the source of resistance in using technology as part of teaching and learning emanated from two main subthemes as perceptions: (1) technology viewed as a fad with little or no impact on actual learning and (2) challenges concerning institutional technology support as a limitation in integrating technology into teaching and learning. Secondly, the change of attitude (rather reluctantly) in using technology as part of teaching and learning was because of factors such as peers, the technology 'tech-savvy' student community and also a consideration for future career prospects as digital and ICT literacies are becoming a critical skills acumen for career progression. Finally, in developing digital and ICT literacies, the lecturers relied on: (1) participation in training programmes that encourage digital scholarship, (2) personal investment of time and effort to learn about how to develop digital and ICT literacies and lastly, (3) developing a career and identity management strategy that incorporates digital and ICT literacies. Implications for teaching and learning practice are made based on these findings. Further, the impact on individual career development (as far as lecturers are concerned) is also suggested.

\section{Introduction}

Information communication technology (ICT) is becoming popular, especially within a university campus scenario both, as a learning tool (Chinyamurindi \& Shava 2015) and as a form of communication (Shava, Chinyamurindi \& Somdyala 2016). According to Nyambane and Mzuki (2014), the rapid growth of ICT has brought about remarkable changes in the 21st century. A notable change, especially within the university campus, is the role of ICT in educational delivery. Notably, empirical studies (mostly in a South African setting) to this end have commonly been focussed on students as end-users (e.g. Chinyamurindi \& Shava 2015; Shava et al. 2016). The processes that end-users, such as teachers and faculty members, engage in their adoption and use of technology are argued as key in effective delivery using ICT (Tiba, Condy \& Junjera 2016). This warrants further investigation, also given contextual and sociohistorical issues surrounding South Africa (Khunou 2015). Further, there appears to be a lot of government support in the use of ICT, as a way of widening access to education albeit, the landscape of discrimination the country is coming from (South African Department of Education 2006). To this end, the need to develop ICT policy and skills is argued for (Blignaut \& Els 2010) by creating life-long learners (South African Department of Education 2004). Priority in all this is also on developing skills that allow teachers and those in management and administration to help students in using ICTs. 
Despite the implementation of e-education in South Africa, there seems to be a slow rate of adoption and use of technology in the classroom (Tiba et al. 2016). Notably, empirical studies pay less attention to how this happens in two scenarios. Firstly, within a context of rapid ICT usage, especially amongst students as end-users. Secondly, within a context of individual career development. This research pays cadence to these two contexts and seeks to explore how a sample of university lecturers develop digital literacies as part of their career development.

\section{Literature review}

This research is based on a theoretical lens that seeks to understand the adoption of technology amongst lecturers. In achieving this, theoretical consideration is given to the technology acceptance model (TAM) (Venkatesh \& Davis 2000). This model consists of two beliefs, namely perceived usefulness and perceived ease of use of the application. These two views determine attitudes towards the adoption of a new technology. The attitude towards adoption depicts the prospective adopter's positive or negative orientation or behaviour towards incorporating a new technology (Venkatesh \& Davis 2000). Usage could also be influenced by an individual's perception of the ability to use the technology (Compeau \& Higgins 1995). Subsequently, all these elements of TAM can serve as predictors of human behaviour (Fishbein \& Ajzen 1975; Lee \& Lehto 2013) or behavioural intention to use, thus resulting in TAM being seen as a useful predictor in explaining human behaviour concerning technology acceptance (Chinyamurindi \& Louw 2010; Chinyamurindi \& Shava 2015; Saadé, Nebebe \& Tan 2007).

The TAM is built around the theory of reasoned action (TRA) (Fishbein \& Ajzen 1975), which suggests that individual behaviour is initiated by the intention to perform a particular task. The result of this is that individual behavioural intention determines one's attitude and subjective norms regarding the behaviour in question (Fishbein \& Ajzen 1975). The TRA also posits that intention to act determines behaviour, and a causal link is believed to exist between the two (Venkatesh \& Davis 2000). The attitude-behavioural intention relationship, as espoused in the TAM constructs, assumes that all intentions to use technology are equal and can be formed on the basis of the positive use of the technology.

The rapid advancement in ICT has unceasingly changed the nature of teaching and learning in higher education (Voogt 2010). The traditional teacher-centred approaches are now being replaced by dynamic and interactive student-centred learning environments because of the new emerging technology (Davis 2002). The new generations of teachers are now expected to be not only an excellent source of information about curriculum design and delivery but also an agent who is supposed to minimise the gap between how technology is applied in classroom teaching and the opportunities offered by technology to enhance student learning (Northcote \& Lim 2009). According to Khan, Bibi and Hason (2016) for teachers to keep up with global pace, they need to be sufficiently competent in using ICT in educational settings.

A study conducted by Buabeng-Andoh (2012) found a positive correlation between ICT use and competences. This finding is consistent with Sorgo, Verckovnik and Kocijancic (2010) who found a high correlation between frequency of use of ICT, perceived value and teachers' competence in the use of ICT amongst science teachers. They further concluded that teachers' competence and confidence were predictors of the role of ICT in teaching. Similarly, the findings by Petrogiannis (2010) concluded that computer-experienced teachers were more ready to use ICT in their classes than non-experienced teachers. Thus, the lack of familiarity with advanced functionalities may be the main reason for teachers not attempting to use ICT (Blin \& Munro 2008).

Teachers are expected to use technology in innovative ways that provide students with an engaging and empowering learning experience to prepare them to interact with a globally networked society (Kopcha, Rieber \& Walker 2016). Research indicates that the effective use of technology in higher education teaching and learning is one of the factors contributing towards the improvement in the quality of instruction (Khan et al. 2016). A study conducted by Collins (2013) provided evidence about the positive effects of using ICT in teaching and learning situations. Information communication technologies have great potential for knowledge dissemination, effective learning and the development of more efficient educational services (BuabengAndoh 2012). This was also found by Koehler and Mishra (2005) that ICT alone cannot lead students to learn; however, teachers who incorporate ICT into their teaching can also facilitate student's learning (Khan 2015).

An essential aspect of the shift in technological processes has been to the acceptance and use of ICT for teaching and learning (Oye, Iahad \& Ab.Rahim 2011). According to Buabeng-Andoh (2012), the adoption of ICT by education has been seen as a powerful way to contribute to educational change, better prepare students for the information age, improve learning outcomes and competencies of learners, and equip students with survival skills for the information society. Therefore, teachers are expected to integrate ICT into their teaching and learning processes. For instance, an analysis by Hue and Ab Jalil (2013) of the relationship between lecturers' attitudes towards ICT integration into the curriculum and their use of ICT in the classroom suggests that when lecturers' attitudes towards ICT integration into curriculum increase, there is a possibility that their ICT use will also increase. Furthermore, to successfully initiate and implement educational technology in the school programme depends strongly on the teachers' support and attitudes. It is believed that if teachers perceived technology programmes as neither fulfilling their own needs nor their students' needs, it is likely that they will not integrate the technology into teaching and learning (Buabeng-Andoh 2012). 
Evidence suggests that teachers' attitudes and beliefs influence successful integration of ICT into teaching (Hew \& Brush 2007; Keengwe \& Onchwari 2008). If teachers' attitudes are positive towards the use of educational technology, then they can easily provide useful insight about the adoption and integration of ICT into teaching and learning processes. Consequently, students learning process and outcomes are connected to their teachers' teaching beliefs, understanding and practices (Khan 2015). For instance, previous studies assert that traditional beliefs that teachers and students hold, have a negative influence on the use of ICT in the classroom (e.g. Hermans et al. 2008; Mäkitalo-Siegl, Kohnle \& Fischer 2011). A study conducted by Drent and Meelissen (2008) on factors that influence the innovative use of ICT by teacher educators in the Netherlands revealed that student-oriented pedagogical approach, positive attitude towards computers, computer experience and personal entrepreneurship of the teacher educator have a direct positive influence on the innovative use of ICT by the teacher.

On the contrary, previous studies suggest that a small number of teachers believe that the benefits of ICT are not seen (Buabeng-Andoh 2012). The empirical survey revealed that one-fifth of European teachers thought that the use of ICT in teaching did not benefit their students' learning (Korte \& Husing 2007). A survey of the United Kingdom (UK) teachers also revealed that teachers' positivity about the possible contributions of ICT was moderated as they became 'rather more ambivalent and sometimes doubtful' about 'specific, current advantages' (Becta 2008: 45).

Furthermore, it has been found that lack of access to equipment in the classroom and lack of teachers' training skills in the use of the equipment contribute to the low use of ICT by teachers (Buabeng-Andoh 2012). Similarly, the study conducted by Howie, Muller and Paterson (2005) found that lack of computer literacy amongst teachers, lack of training with regard to integration of ICT into teaching and the absence of a properly developed computer skills curriculum were barriers to teachers' application of the technology. Therefore, the inconsistency between teachers' actual use of ICT and perception can be attributed to an inadequate supply of ICT resources, lack of access to the right kinds of technology, inadequate ICT pedagogical training and insufficient administrative support (Buabeng-Andoh 2012).

\section{Research methodology}

This research adopted a qualitative methodology hinging on the interpretivist philosophy and using an exploratory research design (Creswell 2009; Silverman 2013). The qualitative approach is praised for the way it allows for gaining a deeper understanding of the lived experience (Sheard 2011) and effective in arriving at making some sense around this experience (Chinyamurindi 2012, 2016a, 2016b).

\section{Research context}

The research project was conducted at a South African university in the Eastern Cape province of South Africa where the authors of this article are based. This research was part of a research component of a qualification of the postgraduate diploma in higher education that one of the authors of this article was part of. This research followed the institutional ethical requirements of the participating institution.

\section{Participant sampling and data collection}

A total of 20 participants took part in the study. The breakdown of these participants was as follows: 10 were males (50\%); 10 were females (50\%); age range was $23-52$ years; average age was 25 years; 15 black people $(75 \%)$ and 5 white people $(25 \%)$. Table 1 shows some description of the participants who took part in this study.

A convenience sampling approach was used relying on those participants who were 'accessible and available' (Cohen, Manion \& Morrison 2013:114). Participants had to be fulltime members of staff with the participating university. Contact and recruitment of the 20 participants were made through an email sent by the researchers explaining the nature of the project and the expectations. Upon agreeing to be part of the study, an interview was arranged at a venue deemed suitable by the prospective respondent. Following all this, a semi-structured interview approach was used following a predetermined structure of questions (Silverman 2013). The study (including interviews) was conducted from May 2015 to May 2016, and each interview lasted between $55 \mathrm{~min}$ and $1.5 \mathrm{~h}$.

\section{Strategies to ensure data quality}

To ensure data quality, four steps were taken. Firstly, initial interview questions were pretested with a sample of 10 postgraduate students on similar characteristics as those participants who took part in the study. These students were also teaching, employing a blended learning approach that employs technology and traditional classroom delivery. Secondly, to ensure credible data, all interview data were recorded and transcribed verbatim within $24 \mathrm{~h}$ has done in previous research (Chinyamurindi 2016a, 2016b). Thirdly, after data transcription, participants were emailed a copy of the transcript to verify its accuracy. Any changes were made to the transcript as per the wish of the participant. Lastly, comprehensive notes were taken during the data collection process, and that assisted in the collection and analysis of data. In essence, this was a point of reflexivity (Taylor, Gibbs \& Lewins 2005) and achieving some sensitivity (Mays \& Pope 2000) in the collection and analysis of data.

\section{Data analysis}

The interviews were exported into QSR International's NVivo 9, a data analysis and management software package useful when dealing with masses of text, graphic, audio and 
TABLE 1: Participant profiles.

\begin{tabular}{|c|c|c|c|c|}
\hline Participant (pseudonym) & WP & ICT K & $\mathbf{G}$ & $\mathbf{P}$ \\
\hline Anna & 7 & Good & Female & Lecturer \\
\hline Sly & 5 & Good & Male & Lecturer \\
\hline Jane & 10 & Good & Female & Senior Lecturer \\
\hline Danny & 11 & Excellent & Male & Associate Professor \\
\hline Dorich & 5 & Good & Male & Lecturer \\
\hline Shivon & 5 & Good & Male & Lecturer \\
\hline Brian & 4 & Excellent & Male & Lecturer \\
\hline Indor & 5 & Good & Female & Lecturer \\
\hline Gauna & 9 & Excellent & Male & Senior Lecturer \\
\hline Chigo & 9 & Good & Female & Senior Lecturer \\
\hline Thaimi & 7 & Good & Male & Senior Lecturer \\
\hline Jolif & 9 & Excellent & Female & Senior Lecturer \\
\hline Kevon & 10 & Good & Male & Associate Professor \\
\hline Jacob & 11 & Good & Male & Associate Professor \\
\hline Jo & 10 & Good & Female & Associate Professor \\
\hline Pat & 13 & Good & Female & Senior Lecturer \\
\hline Simone & 15 & Excellent & Female & Associate Professor \\
\hline Marjorie & 13 & Good & Female & Associate Professor \\
\hline
\end{tabular}

WP, work experience; ICT K, information communication technology knowledge; G, gender; P, position.

video data (Reuben \& Bobat 2014). Thematic analysis was used as a means of data analysis (Braun \& Clarke 2006). Thematic analysis is viewed as a flexible and useful research tool because of its ability to potentially provide a rich and detailed yet complex account of data (Clarke \& Braun 2013). The process of generating themes is believed to happen at two levels: (1) semantic level and (2) latent level (Braun \& Clarke 2006).

At the semantic level, themes are identified within the explicit of the surface of meanings of the data and the analyst is not looking for anything beyond what a respondent has said or written; on the contrary, thematic analysis at the latent level seeks to identify or examine underlying ideas that are theorised as shaping or influencing the semantic content of the data (Braun \& Clarke 2006). A semantic level approach was used for this research and this entailed an analytic process which involves a progression from description where the data have been organised to show patterns in semantic content and summarised, to interpretation, where there is an attempt to theorise the significance of the patterns and their broader meanings and implications in relation to previous literature (Braun \& Clarke 2006).

\section{Research results}

Drawing from the data analysis, three main findings emerged. Firstly, the source of resistance in using technology as part of teaching and learning emanated from two main subthemes as perceptions: (1) technology viewed as a fad with little or no impact on actual learning and (2) challenges concerning institutional technology support as a limitation in integrating technology into teaching and learning. Secondly, the change of attitude (rather reluctantly) in using technology as part of teaching and learning was because of factors such as peers, the 'tech-savvy' student community and also a consideration for future career prospects as digital and ICT literacies are becoming a critical skills acumen for career progression. Finally, in developing digital and ICT literacies, the lecturers relied on: (1) participation in training programmes that encourage digital scholarship, (2) personal investment of time and effort to learn how to develop digital and ICT literacies and lastly, (3) developing a career and identity management strategy that incorporates digital and ICT literacies. Table 2 highlights the development of these themes stemming from the initial codes that are generated.

\section{Source of resistance}

Based on the data analysis, two main sources of resistance towards technology usage in teaching and learning were identified. Table 3 presents these sources of resistance.

From Table 3 some accounts can be used as examples. For instance, Marjorie was resistant towards using technology drawing on the years of work experience that she has.

'I have been in academia for over ten years now. I would say when the technology movement started I was sceptical. It appears there is always a fascination with tools and yet the core issue of teaching and learning is not changing.' (Marjorie, female, associate professor)

This view by Marjorie was confirmed by another participant:

'It seems we are in a state of flux in higher education today. An endless excitement with tools and pedagogical resources hinging on technology. I understand why we lecturers can be resistant. To keep up with all these tools and resources is a mission. What does not change are the basics, these are the basics from which our teaching and learning are grounded in.' (Brian, male, lecturer)

Linked to this subtheme and derived from Table 3 are experiences that also reveal a failure of institutional 
TABLE 2: Development of themes: Initial codes to resultant themes.

\begin{tabular}{ll}
\hline Initial codes & Resultant themes \\
\hline - Scepticism of using the technology & Technology as a fad \\
- Negative feelings around technology & \\
- Internalions about technology usage & \\
- Software challenses & \\
- Hardware challenges & \\
- Role of peers & \\
- Staff support & Peer influence \\
- Collegial spirit & \\
- Changing type of learners & \\
- Student influence & Tech-savvy students \\
- 21 st century learner needs & \\
- Promotion prospects & \\
- Tenure & Future career prospects \\
- Career prospects & \\
- Training efforts & \\
- HRD efforts & Participation in training \\
- Agency & \\
- Initiative and drive & Personal investment \\
- Self-marketing efforts & \\
- Awareness of oneself & Career and identity management \\
\hline
\end{tabular}

ICT, Information ommunication echnology.

authorities in helping address fears and concerns lecturers have regarding technology usage. For instance, Shivon cited an experience:

'Last year, I had a class of 200 from a course that usually hosted 80 students. So I approached the relevant authorities to see how technology can help as I had taught without technology. The whole process took at least three weeks to set-up, and for me, it was just not worth the delay. Mainly due to an internal issue that can easily be solved.' (Shivon, male, lecturer)

Other participants like Vanessa cited an institutional disparity to exist concerning the use of technology:

'For instance, a student can take eight courses a semester. Meaning they have eight different lecturers. Each of these has their way of teaching. Some use technology and others don't. Do you see the confusion it creates? In my view, there is more support for traditional classroom learning than the electronic aspect.' (Vanessa, female, senior lecturer)

\section{Sources causing the change of attitude}

After five months, the second stream of interviews was conducted with the same 20 participants and the aim here was to understand the experiences in using technology albeit the initial views of resistance. Our concern was the sources that may change an attitude to favour technology usage. Table 4 presents a list of these sources of change and some quotes to support these.

\section{How lecturers develop digital literacies?}

Finally, in developing digital and ICT literacies, the lecturers relied on: (1) participation in training programmes that encourage digital scholarship, (2) personal investment of time and effort to learn how to develop digital and ICT literacies; and lastly, (3) developing a career and identity management strategy that incorporates digital and ICT literacies. Table 5 presents the illustrating quote for this finding.
TABLE 3: Sources of resistance to technology usage.

\begin{tabular}{ll}
\hline Source & Illustrating quotes \\
\hline Technology as a fad & 'The real metric for me is student throughput rates. If I get \\
there through the traditional approach, it does not matter. \\
Technology just makes things complex, yet the metrics are \\
still the same'. Anna \\
'If students are passing and there is evidence to this through \\
me standing in front of them, I don't see what the problem is. \\
Technology has helped with keeping useful data, especially \\
around at-risk students. Challenges outweigh benefits for me. \\
These affect my attitude towards using technology'. Jolif \\
'The resistance appears to emerge from challenges within the \\
system. For instance, the issue of pass rates. We get to a point \\
where we have to choose between the objective and the \\
subjective. Pass rates are objective, and experience of using \\
technology is subjective. I prefer that which my career is \\
based on, the former.' Danny \\
'So, what happens when the technology is down - for this is a \\
reality I have experienced and makes me sceptical of \\
technology in teaching instruction.' Indor \\
'A help desk should be available 24 hours. For instance, when \\
students need help accessing the Learning Management \\
System in the early hours of the morning who is there to help \\
them?' Jane \\
'We need support, and this starts from the highest office on \\
the campus and trickles to our students. The absence of such \\
support is tantamount to failure.' Thaimi
\end{tabular}

TABLE 4: Sources causing the change of attitude.

\begin{tabular}{ll}
\hline Source & Illustrating quotes \\
\hline Peer influence & My colleagues have been the greatest influence on my \\
adoption and use of technology over the years. I guess \\
iron sharpens iron and that is what we have had to do as \\
more senior academics.' Marjorie \\
'One of my peers took me through a crash course to \\
understand dynamics of Blackboard, our Learning \\
Management System. This made the difference for me \\
and helped change my view of the worth of technology \\
instruction.' Jacob \\
We work in communities of practice in academia. \\
These are also communities of collaboration. So it \\
becomes mandatory to tap into the skills of those who \\
can do what you can't do. Over the years this has been \\
the lesson I learnt given technology usage'. Pat \\
'Our students force you to be relevant. None but their \\
use of technology heightens this issue.' Kevon \\
'Think of standing in a class with 80 students who are \\
information hungry and with devices that make such \\
information easy to access. You have no choice but \\
always to keep up.' Progress \\
'It comes down to relevance. To be relevant understand \\
your constituents. This involves understanding the \\
tools they use. Without this, you are just irrelevant.' \\
Gauna
\end{tabular}

\section{Discussion and conclusion}

This study sought to explore how a sample of university lecturers develop digital literacies as part of their career development. The backdrop of this being a context where South Africa is viewed as becoming a country that places priority on the adoption and use of technology in the classroom (Tiba et al. 2016). In support of the observation of the rapid change brought about by ICT (Nyambane \& Mzuki 2014), this research illustrates factors that affect lecturers as part of the knowledge generation process albeit 
TABLE 5: How digital and information communication technology literacies develop?

\begin{tabular}{|c|c|}
\hline Source & Illustrating quotes \\
\hline \multirow[t]{3}{*}{ Participation in training } & $\begin{array}{l}\text { 'I signed up for a course organised by GetSmart, and this } \\
\text { helped get the latest skills-set concerning technology } \\
\text { usage.' Kevon }\end{array}$ \\
\hline & $\begin{array}{l}\text { 'Our Teaching and Learning Centre organises some } \\
\text { training workshops and forums that help make us aware } \\
\text { of the latest happenings and also share best practices.' } \\
\text { Pat }\end{array}$ \\
\hline & $\begin{array}{l}\text { 'When I attended a teaching and learning conference } \\
\text { there was a special session of ICT and digital skills. } \\
\text { Ever since I attend this conference every year in Durban } \\
\text { to hone my skills.' Progress }\end{array}$ \\
\hline \multirow[t]{3}{*}{ Personal investment } & $\begin{array}{l}\text { 'I make an effort to subscribe to different blogs and } \\
\text { viewpoints to empower myself.' Simone }\end{array}$ \\
\hline & $\begin{array}{l}\text { 'You are the master of your destiny. When you realise } \\
\text { this, you make an effort to create this destiny by taking } \\
\text { proactive steps.' Brian }\end{array}$ \\
\hline & $\begin{array}{l}\text { 'There is no substitute for investment than a personal } \\
\text { investment to keep abreast of changes happening.' Jo }\end{array}$ \\
\hline \multirow[t]{3}{*}{$\begin{array}{l}\text { Career and identity } \\
\text { management }\end{array}$} & $\begin{array}{l}\text { 'I have now invested in belonging to a range of social } \\
\text { networking sites and professional societies as part of } \\
\text { managing my career. This allows me to learn from others } \\
\text { around the clock.' Thaimi }\end{array}$ \\
\hline & $\begin{array}{l}\text { 'A friend recommended a consult a technologist who is } \\
\text { independent as part of trying to find ways to improve my } \\
\text { impact not just as a teacher but also as part of my career } \\
\text { identity beyond this institution.' Anna }\end{array}$ \\
\hline & $\begin{array}{l}\text { 'Part of all this is an awareness of what I am becoming as } \\
\text { part of the experience. Thus, each experience deserves to } \\
\text { be managed with thoughtfulness as it forms part of the } \\
\text { whole experience. I have stopped complaining and } \\
\text { started managing issues. This has allowed me to embrace } \\
\text { technology as a friend than a foe.' Danny }\end{array}$ \\
\hline
\end{tabular}

the uncomfortable in some cases. So in a bid to create lifelong learners, Blignaut and Els (2010) suggested that the focus should also be on understanding how to empower those mandated with the responsibility to develop such learners, and this heightens the focus on university lecturers. Although a possible tension exists, as illustrated by this study, between a traditional approach to learning (Voogt 2010) and a contemporary perspective (Khan et al. 2016), some form of compromise can be arrived at. For instance, the participants of the study narrated their concerns about technology usage and a possible reason for their negative attitude. However, these concerns should not be dismissed as these can have utility functions. Firstly, they can be a basis for interventions to improve teaching delivery, using technology, may be suggested (Sorgo et al. 2010). Secondly, as illustrated by the findings, these concerns help improve understanding the lived experience, concerning technology usage in teaching delivery and ultimately do affect the career prospects of the lecturers. Finally, following these concerns creates a platform to identify best practices concerning ICT use and the competencies needed (Petrogiannis 2010). This can affect full-system utilisation (Davis 2002).

This research supports previous South African research that shows the popularity of the use of technology in teaching and learning (Chinyamurindi \& Shava 2015). Previous research attested to this popularity by paying attention to end-user perspective as a focus on students (Chinyamurindi \& Shava 2015; Shava et al. 2016). This research magnifies the attention of the lecturer as an important stakeholder, not only in the generation of knowledge but also how it is presented. Such a focus on the lecturer as a user of ICT for teaching practice gives cadence to the importance of empowering this constituent group as part of the deliverables of their jobs (Tiba et al. 2016). Through the findings of this research, contextual issues, as probed in previous South African studies were key in influencing the adoption of technology amongst teaching staff (Khunou 2015). Thus, the lecturing and teaching staff may be considered to be life-long learners as well (Blignaut \& Els 2010).

The source of resistance by the lecturers to technology could be attributed to the pressures from the context they are operating within (Tiba et al. 2016). Emphasis within this context is on the need to meet deliverables to an everchanging student constituency that is technologically savvy. Thus, students indirectly drive this pressure that requires lecturers to not only catch up with the latest technology but also be users themselves. Thus, the change brought about by the use of ICTs has created this different atmosphere (Nyambane \& Mzuki 2014). The resistance towards technology as found in this study could be indicative of generational challenges that exist within the academy. Two contesting views seem to exist, firstly, a traditional teachercentred approach and the latter, a more contemporary perspective with emphasis on technology usage (Davis 2002). This generational gap manifests in different approaches to learning and plays a key role in the resistance to ICTs. This study illustrates how this links to the individual career development against the teachers. Guided by the literature, lecturers may need to make the transition between the identified gaps to allow them to efficiently and effectively meet the needs of the 21st century learner (Khan et al. 2016). Institutions of higher learning may need to come in and assist this process through empowerment initiatives.

The study has some contributions. Firstly, it advances the literature within a South African setting that concerns aspects of ICT literacies (Chinyamurindi \& Shava 2015; Shava et al. 2016). Whereas previous studies have focussed on student samples, this research locates its argument by giving voice to university lecturers. This sample is as important as the student sample (yet under-researched) as argued by other researchers (Tiba et al. 2016). Further, the research heightens the focus on the role of context in shaping aspects of technology usage (Khunou 2015). The findings of this study do much to highlight those issues from a lecturer's perspective that can help to create a better working context as far technology is concerned.

The current work has some limitations. Firstly, because of the qualitative nature of the research, generalisability is not possible as the findings are subjective based on a lived experience. Thus, the results of this research are not generalisable to the entire population of university lecturers in South Africa. We thus urge caution when interpreting and making implications based on this. Secondly, this research does not reveal an accurate demographic profile of the lecturers in the selected university as participants were conveniently selected. Despite these limitations within this research, future research can be enacted to improve on these 
limitations. Further, a quantitative research approach can be used to improve the subjective limitation of this research. This allows for a more representative sample. Inferences can also be made to establish linkages and association between the variables being studied.

In conclusion, one participant of this study spoke of the challenge they face and a possible solution:

'Can you teach an old dog new tricks? This is an insult to an old dog. You can teach a dog anything, just as long as it wants to learn.' (Progress, male, full professor)

\section{Acknowledgements}

The authors thank all the participants for taking part in this research.

\section{Competing interests}

The authors declare that they have no financial or personal relationships which may have inappropriately influenced them in writing this article.

\section{Authors' contributions}

W.T.C. collected and analysed the data. Z.D. wrote the initial draft of the article and also assisted in data collection.

\section{References}

Becta, 2008, Harnessing technology: Schools survey 2008, viewed 20 January 2017, from http://emergingtechnologies.becta.org.uk/uploaddir/downloads/ page documents/research/ht schools survey08 analysis.pdf

Blignaut, A.S. \& Els, C.J., 2010, 'Comperacy assessment of postgraduate students' readiness for higher education', The Internet and Higher Education 13(3), 101107. https://doi.org/10.1016/j.iheduc.2010.02.007

Blin, F. \& Munro, M., 2008, 'Why hasn't technology disrupted academics' teaching practices? Understanding resistance to change through the lens of activity theory", Computers \& Education 50(2), 475-490. https://doi.org/10.1016/j.compedu. 2007.09.017

Braun, V. \& Clarke, V., 2006, 'Using thematic analysis in psychology', Qualitative Research in Psychology 3(2), 77-101. https://doi.org/10.1191/1478088706qp063oa

Buabeng-Andoh, C., 2012, 'An exploration of teachers' skills, perceptions and practices of ICT in teaching and learning in the Ghanaian second-cycle schools', Contemporary Educational Technology 3(1), 36-49.

Chinyamurindi, W. \& Shava, H., 2015, 'An investigation into e-learning acceptance and gender amongst final year students', South African Journal of Information Management 17(1), 1-9. https://doi.org/10.4102/sajim.v17i1.635

Chinyamurindi, W.T., 2012, 'An investigation of career change using a narrative and story-telling inquiry' South African Journal of Human Resource Management 10(2), 1-11. https://doi.org/10.4102/sajhrm.v10i2.447

Chinyamurindi, W.T., 2016a, 'Using narrative analysis to understand factors influencing career choice in a sample of distance learning students in South Africa', South African career choice in a sample of distance learning students in South Africa', South African
Journal of Psychology 46(3), 390-400. https://doi.org/10.1177/0081246315623662

Chinyamurindi, W.T., 2016b, 'A narrative investigation into the meaning and experience of career success: Perspectives from women participants', South African Journal of Human Resource Management 14(1), 1-11. https://doi.org/10.4102/sajhrm. v14i1.659

Chinyamurindi, W.T. \& Louw, G.J., 2010, 'Gender differences in technology acceptance in selected South African companies: Implications for electronic learning: Origina research', SA Journal of Human Resource Management 8(1), 1-7. https://doi. org/10.4102/sajhrm.v8i1.204

Clarke, V. \& Braun, V., 2013, 'Teaching thematic analysis: Overcoming challenges and developing strategies for effective learning', The Psychologist 26(2), 120-123.

Cohen, L., Manion, L. \& Morrison, K., 2013, Research methods in education, Routledge, New York.

Collins, T., 2013, 'Supporting teachers to embed flexible learning technologies in their teaching practice: A case study', National vocational education and training research program occasional paper, NCVER, Adelaide.

Compeau, D.R. \& Higgins, C.A., 1995, 'Computer self-efficacy: Development of a measure and initial test', MIS Quarterly 19(2), 189-211. https://doi.org/10.2307/ 249688
Creswell, J.W., 2009, 'Mapping the field of mixed methods research', Journal of Mixed Methods Research 3(2), 95-108. https://doi.org/10.1177/1558689808330883

Davis, N., 2002, 'Leadership of information technology for teacher education: A discussion of complex systems with dynamic models to inform shared leadership', Journal of Information Technology for Teacher Education 11, 253-272. https://doi.org/10.1080/14759390200200136

Drent, M. \& Meelissen, M., 2008, 'Which factors obstruct or stimulate teacher educators to use ICT innovatively?', Computers \& Education 51(1), 187-199. https://doi.org/10.1016/j.compedu.2007.05.001

Fishbein, M. \& Ajzen, I., 1975, Belief, attitude, intention, and behaviour: An introduction to theory and research, Addison-Wesley, Reading, MA.

Hermans, R., Tondeur, J., van Braak, J. \& Valcke, M., 2008, 'The impact of primary school teachers' educational beliefs on the classroom use of computers', Computers \& Education 51, 1499-1509. https://doi.org/10.1016/j.compedu. 2008.02.001

Hew, K.F. \& Brush, T., 2007, 'Integrating technology into K-12 teaching and learning: Current knowledge gaps and recommendations for future research', Educationa Technology Research \& Development 55, 223-253. https://doi.org/10.1007/ s11423-006-9022-5

Howie, S.J., Muller, A. \& Paterson, A., 2005, Information and communication technologies in South African secondary schools, HSRC Press, Pretoria.

Hue, L.T. \& Ab Jalil, H., 2013, 'Attitudes towards ICT integration into curriculum and usage among university lecturers in Vietnam', International Journal of Instruction usage amon

Keengwe, J. \& Onchwari, G., 2008, 'Computer technology integration and student learning: Barriers and promise', An International Journal of Science Education and Technology 17, 560-565. https://doi.org/10.1007/s10956-008-9123-5

Khan, S.H., 2015, 'Emerging conceptions of ICT-enhanced teaching: Australian TAFE context', Instructional Science: An International Journal of the Learning Sciences 43(6), 683-708. https://doi.org/10.1007/s11251-015-9356-7

Khan, S.H., Bibi, S. \& Hason, M., 2016, 'Australian technical teachers' experience of technology integration in teaching', SAGE Open 6(3), 1-12. https://doi.org/ $10.1177 / 2158244016663609$

Khunou, G., 2015, 'What middle class? The shifting and dynamic nature of class position', Development Southern Africa 32(1), 90-103. https://doi.org/10.1080/0 376835X.2014.975889

Koehler, M.J. \& Mishra, P., 2005, 'What happens when teachers design educational technology? The development of technological pedagogical content knowledge' Journal of Educational Computing Research 32(2), 131-152. https://doi. org/10.2190/0EW7-01WB-BKHL-QDYV

Kopcha, T.J., Rieber, L.P. \& Walker, B.B., 2016, 'Understanding university faculty perceptions about innovation in teaching and technology', British Journal of Educational Technology 47(5), 945-957. https://doi.org/10.1111/bjet.12361

Korte, W.B. \& Husing, T., 2007, 'Benchmarking access and use of ICT in European schools 2006: Results from head teacher and a classroom surveys in 27 European countries', E-learning Papers 29(10), 1-6.

Lee, D.Y. \& Lehto, M.R., 2013, 'User acceptance of YouTube for procedural learning: An extension of the technology acceptance model', Computers and Education 61 193-208. https://doi.org/10.1016/j.compedu.2012.10.001

Mäkitalo-Siegl, K., Kohnle, C. \& Fischer, F., 2011, 'Computer-supported collaborative inquiry learning and classroom scripts: Effects on help-seeking processes and
learning outcomes', Learning and Instruction 21, 257-266. https://doi. learning outcomes', Learning and
org/10.1016/j.learninstruc.2010.07.001

Mays, N. \& Pope, C., 2000, 'Qualitative research in health care: Assessing quality in qualitative research', BMJ: British Medical Journal 320(7226), 50. https://doi. qualitative research', $B M J$ : $B r$ ris
org $/ 10.1136 / \mathrm{bmj} .320 .7226 .50$

Northcote, M. \& Lim, C.P., 2009, 'The state of pre-service teacher education in the Asia-Pacific region', in C.P. Lim, K. Cock, G. Lock \& C. Brook (eds.), Innovative practices in pre-service teacher education: An Asia-Pacific perspective, pp. 23-28, practices in pre-service teacher education:
Sense Publishers, Rotterdam, Netherlands.

Nyambane, C.O. \& Nzuki, D., 2014, 'Factors influencing ICT integration in teaching - A literature review', International Journal of Education and Research 2(3), 136-155.

Oye, N.D., lahad, N.A. \& Ab.Rohim, N., 2011, 'Adoption and acceptance of ICT innovation in Nigerian public universities', International Journal of Computer Science Engineering and Technology 1(7), 434-443.

Petrogiannis, K., 2010, 'The relationship between perceived preparedness for computer use and other psychological constructs among kindergarten teachers with and without computer experience in Greece', Journal of Information Technology Impact 10(2), 99-110.

Reuben, S. \& Bobat, S., 2014, 'Constructing racial hierarchies of skill - Experiencing affirmative action in a South African organisation: A qualitative review', $S A$ Journal of Industrial Psychology 40(1), 1-12. https://doi.org/10.4102/sajip. v40i1.1158

Saadé, R.G., Nebebe, F. \& Tan, W., 2007, 'Viability of the technology acceptance mode in multimedia learning environments: A comparative study', Interdisciplinary Journal of Knowledge and Learning Objects 3(1), 175-184. https://doi. org/10.28945/3076

Shava, H., Chinyamurindi, W. \& Somdyala, A., 2016, 'An investigation into the usage of mobile phones among technical and vocational educational and training students in South Africa', South African Journal of Information Management 18(1), 1-8. https://doi.org/10.4102/sajim.v18i1.716

Sheard, L., 2011, 'Anything could have happened: Women, the night-time economy, alcohol and drink spiking', Sociology 45(4), 619-633. https://doi.org/10.1177/ 0038038511406596 
Silverman, D., 2013, Doing qualitative research: A practical handbook, Sage Publications Limited, London.

Sorgo, A., Verckovnik, T. \& Kocijancic, S., 2010, 'Information and communication technologies (ICT) in biology teaching in Slovenian secondary schools', Eurasia Journal of Mathematics, Science and Technology Education 6, 37-46.

South African Department of Education, 2004, White paper on e-education: Transforming learning and teaching through information and communication technologies (ICTs), viewed 26 July 2006, from http://www.info.gov.za/ whitepapers/2003/e-education.pdf

South African Department of Education, 2006, Annual report 2005/2006, viewed 15 April 2008, from http://www.education.gov.za/dynamic/dynamic.aspx?pageid $=329 \&$ catid $=10 \&$ category $=$ Reports \&legtype $=$ nul
Taylor, C., Gibbs, G.R. \& Lewins, A., 2005, Quality of qualitative analysis, viewed 13 September 2017, from http://onlineqda.hud.ac.uk/Intro_QDA/qualitative_ analysis.php

Tiba, C., Condy, J. \& Junjera, N., 2016, 'Re-examining factors influencing teachers' adoption and use of technology as a pedagogical tool', in South African International Conference on Educational Technologies. Proceedings, Pretoria, April 24-26, 2016, pp. 1-11.

Venkatesh, V. \& Davis, F.D., 2000, 'A theoretical extension of the technology acceptance model: Four longitudinal field studies', Management Science 46(2), 186-204. https://doi.org/10.1287/mnsc.46.2.186.11926

Voogt, J., 2010, 'Teacher factors associated with innovative curriculum goals and pedagogical practices: Differences between extensive and non-extensive ICTusing science teachers', Journal of Computer Assisted Learning 26, 453-464. https://doi.org/10.1111/j.1365-2729.2010.00373.x 